\title{
The effect of opium poppy oil diesel fuel mixture on engine performance and emissions
}

\author{
F. Aksoy \\ Technical Education Faculty, Machine Education Department, Afyon Kocatepe University, Afyonkarahisar, Turkey \\ Received 2 August 2010; $\quad$ revised 15 October 2010; accepted 10 November 2010; available online 1 December 2010
}

\begin{abstract}
Recently, decreasing of fossil fuel reserves and their negative effect on environment have increased the interest in alternative energy sources. One of the alternative energy sources is vegetable oils. In this study, blends of 50 $\%$ opium poppy oil - $50 \%$ diesel fuel mixture are tested as alternative fuel on a single cylinder, 4-stroke, air cooled, precombustion chamber diesel engine at different speeds and its effects on engine performance and emissions are investigated. When compared to the diesel fuel as average, engine torque and power decrease at $4 \%$ and $5.73 \%$, respectively. Specific fuel consumption increases by using of 50\% opium poppy oil - $50 \%$ diesel fuel mixture. When compared to the diesel fuel as average, carbon monoxide and nitrogen oxides emissions of $50 \%$ opium poppy oil - $50 \%$ diesel fuel mixture decrease to $15.5 \%$ and $5.9 \%$, respectively. Diesel fuel-opium poppy oil mixture has been found notably successful and environment friendly as an alternative fuel for diesel engines.
\end{abstract}

Keywords: Alternative energy; Engine; Exhaust emission;Vegetable oil

\section{INTRODUCTION}

Energy needs, which is related with three main factors such as population growth, economical development and technological progress, is an important essential to social and economical development for countries (Kaygusuz and Sarý, 2003; De Oliveira Matias and Devezas, 2007; Panjeshahi and Ataei, 2008). Energy sources are separated into two parts as renewable and non-renewable. Energy obtained by hydro, solar, wind, biomass and wastes are renewable energy sources, while fossil fuels are non-renewable energy sources (Haktanýrlar Ulutas, 2005). In developed and developing countries, fossil fuels are used in diesel engines. Diesel fuels have a negative effect on environment since they include high amounts of sulfur and aromatics. $\mathrm{CO}_{2}, \mathrm{CO}, \mathrm{SO}_{\mathrm{x}}, \mathrm{NO}_{\mathrm{x}}$ and smoke are produced from fossil fueled diesel engine exhaust emissions. $\mathrm{NO}_{\mathrm{x}}$ and $\mathrm{CO}_{2}$ cause greenhouse effect and $\mathrm{SO}_{x}$ cause acid rains (Kalam et al., 2003). Negative effect of fossil fuels on environment and decreasing reserves increase the studies on new fuel types that can be used in motor vehicles (Çevik et al., 2008). One of the alternative energy sources is vegetable oils. Vegetable oils were first used as fuel in diesel engines by Rudolf

\footnotetext{
\.Corresponding Author Email: faksoys@gmail.com Tel.: +90272 2281 311; Fax: +90272 2281319
}

Diesel in 1900 (Ramadhas et al., 2005; Baiju et al., 2009; Agarwal et al., 2008; Agarwal and Rajamanoharan, 2009; Babel et al., 2009). They are produced from plants such as canola, colza, soybean, flax, sunflower seed, and corn. Vegetable oils have several advantages such that they include low level of sulfur, oxygen exists in their structure, their setane number is high, and they give off less harmful emissions when they are burned (Çanakci and Van Gerpen, 1999; Yavuz et al., 2008; Aksoy et al., 2008). In addition, they have a higher flash point and a better lubricating quality (Akta ${ }^{\circ}$ and Sekmen, 2008). There have been performed many studies on the usage of vegetable oils such as palm oil, sunflower seed oil, coconut oil, olive oil, sesame oil, soybean oil, karanja oil, jatropha, orange and jojoba oil in diesel engines as alternative fuels (Kalam and Masjuki, 2004; Huzayyin et al., 2004). Vegetable oils, as fuel for diesel engine have an important potential in short-term engine performance tests (Kalam and Masjuki, 2004; Huzayyin et al., 2004; Refaat, 2010). However, their low volatilities and high viscosities cause problems in long-term engine performance tests. Viscosity, that affects atomization quality, fuel droplet size and penetration, is very important for combustion quality. While low viscosity causes leakage in the fuel system, high 
viscosity causes poor fuel atomization and incomplete combustion (Alptekin and Çanakcý, 2009). In long-term tests, high viscosity is due to the chemical structure of vegetable oils and their high molecular weight leads to problems such as gumming, injector coking with trumpet formation, and ring sticking in diesel engine (Pramanik, 2003; Altun et al., 2008). The methods such as transesterification, pre-heating and blending it with diesel/alcohol are used in order to decrease the viscosity of vegetable oils (Kumar et al., 2003; Refaat et al., 2008; El Diwani and El Rafie, 2008; Refaat, 2009). Among these three methods, blending is preferred since it does not require a long process and it is simple (Altun et al., 2008). In this study, opium poppy oil which has a high viscosity value is mixed with diesel fuel at a rate of $50 \%$ by volume and the effect of the mixture on engine performance and emissions is investigated.

\section{MATERIALS AND METHODS}

Tests are performed on a single cylinder, 4-stroke, air cooled, pre-combustion chamber diesel engine that is used in agriculture industry. Technical specifications of the test engine are given in Table 1. Opium poppy oil that is also

Table 1: The technical specifications of the test engine

\begin{tabular}{lr}
\hline Items & Specifications \\
\hline Numbers of cylinder & 1 \\
Volume $\left(\mathrm{cm}^{3}\right)$ & 668 \\
Bore/stroke $(\mathrm{mm})$ & $90 / 105$ \\
Compression ratio & 21 \\
Cooling system & Air cooled \\
Maximum engine torque $(\mathrm{Nm} / \mathrm{rpm})$ & $36.7 / 1800$ \\
\hline
\end{tabular}

Table 2: The main properties of test fuel

\begin{tabular}{lrr}
\hline Properties & Diesel Fuel & $\begin{array}{r}50 \% \text { Opium Poppy oil } \\
\text { and 50\% Diesel Fuel }\end{array}$ \\
\hline Viscosity $\left(\mathrm{mm}^{2} / \mathrm{s}\right)$ & $4.3\left(\right.$ at $\left.27^{\circ} \mathrm{C}\right)$ & 9.89 \\
Density $\left(\mathrm{kg} / \mathrm{m}^{3}\right)$ & 815 & 878.9 \\
Flash Point $\left({ }^{\circ} \mathrm{C}\right)$ & 58 & 87 \\
Heating Value $(\mathrm{kJ} / \mathrm{kg})$ & 43350 & 42500 \\
Cetane number & 47 & - \\
\hline
\end{tabular}

Table 3: Accuracies of the measurements and the uncertainties in the calculated results

\begin{tabular}{lc}
\hline & Accuracy and uncertainties \\
\hline Fuel $(\mathrm{g})$ & Accuracy $= \pm 1 \mathrm{~g}$ \\
Time $(\mathrm{s})$ & Accuracy $= \pm 0.5 \%$ \\
Torque $(\mathrm{Nm})$ & Uncertainty $= \pm 1 \%$ \\
Power $(\mathrm{kW})$ & Uncertainty $= \pm 1.41 \%$ \\
$\mathrm{SFC}(\mathrm{g} / \mathrm{kWh})$ & Uncertainty $= \pm 1.5 \%$ \\
$\mathrm{CO}(\mathrm{ppm})$ & Accuracy $= \pm 1 \mathrm{ppm}$ \\
$\mathrm{NO}_{x}(\mathrm{ppm})$ & Accuracy $= \pm 1 \mathrm{ppm}$ \\
\hline
\end{tabular}

used as cooking oil in Afyonkarahisar city is used as the test fuel. Opium poppy oil is mixed with diesel fuel at a rate of $50 \%$ by volume since its kinematic viscosity is considerably high. The main properties of the mixture and diesel fuel are given in Table 2. In engine torque measurements, an electric dynamometer having a load cell with a sensitivity of 0.01 is used. After the engine reaches the operating temperature, tests are performed at full load conditions between 1400-2200 rpm engine speed with 200 rpm intervals. Testo 350 XL portable gas analyzer was used for measuring of $\mathrm{CO}$ and $\mathrm{NO}_{\mathrm{x}}$ emissions. The schematic illustration of experimental setup is given in Fig. 1. Information about accuracy of measurement equipments and uncertainties of the calculated results is given in Table 3.

\section{RESULTS AND DISCUSSION}

\section{Engine performance}

The variations of engine torque and power with engine speed are given in Fig. 2 and Fig. 3 for $50 \%$ opium poppy oil - $50 \%$ diesel fuel mixture and diesel fuel, respectively. While Engine power and torque are low at low engine speeds, they increase by increasing of engine speed. Engine torque increases up to 1800 rpm engine speed and it decreases beyond this speed. The engine torque of opium poppy oil-diesel fuel mixture compared with diesel fuel decreased by $3 \%$ at $2000 \mathrm{rpm}$. Engine power increases up to $2000 \mathrm{rpm}$ engine speed for opium poppy oil-diesel fuel mixture and it specifically decreases beyond this speed. Engine power of $50 \%$ opium poppy oil - $50 \%$ diesel fuel mixture compared to the diesel fuel as average decrease to $5.73 \%$. Altýn et al. (2001) observed a $10 \%$ decrease in engine torque compared to diesel fuel in their study conducted using raw sunflower seed oil, raw soybean oil, and opium poppy oil at $1300 \mathrm{rpm}$ engine speed. They observed an $18 \%$ decrease in engine power by using raw cotton and soybean oil at $1700 \mathrm{rpm}$ engine speed. Altun et al. (2008) observed a decrease in engine torque and power compared to diesel fuel for sesame oil - diesel fuel mixture. Çanakçý et al. (2009) observed a $0.82 \%$ increase in engine performance compared to diesel fuel for preheated sunflower seed oil at $1000 \mathrm{rpm}$ engine speed and a $0.75 \%$ decrease at 2000 and 3000 rpm engine speeds. While density and viscosity of fuel mixture is higher than that of diesel fuel, heating value of it is lower than that of diesel fuel. These affect the combustion performance of opium poppy oil-diesel fuel mixture and cause a decrease in engine performance (Altýn et al., 2001; Keskin et al., 2007; Çaynak et al., 2009). 


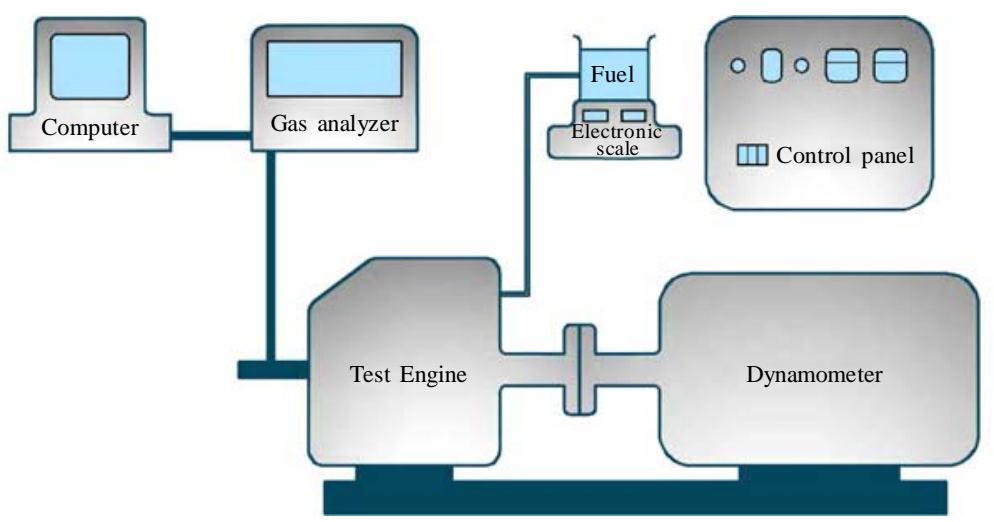

Fig. 1: The schematic illustration of experimental setup

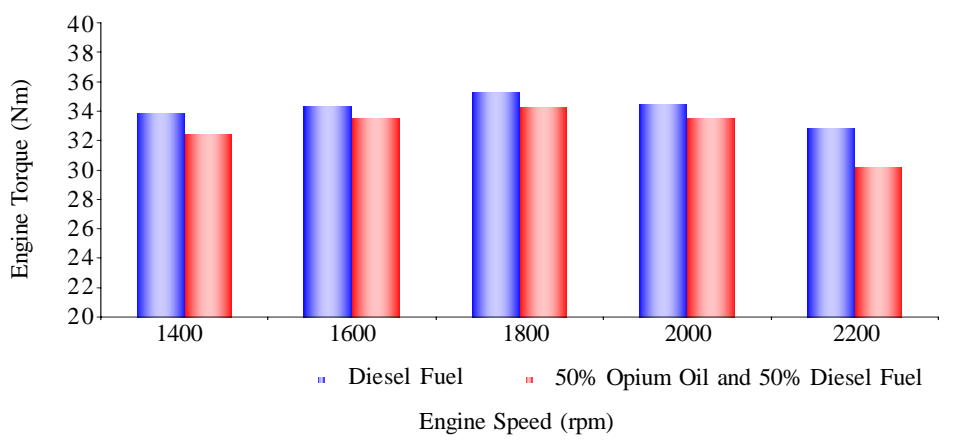

Fig. 2: The variation of engine torque with engine speed

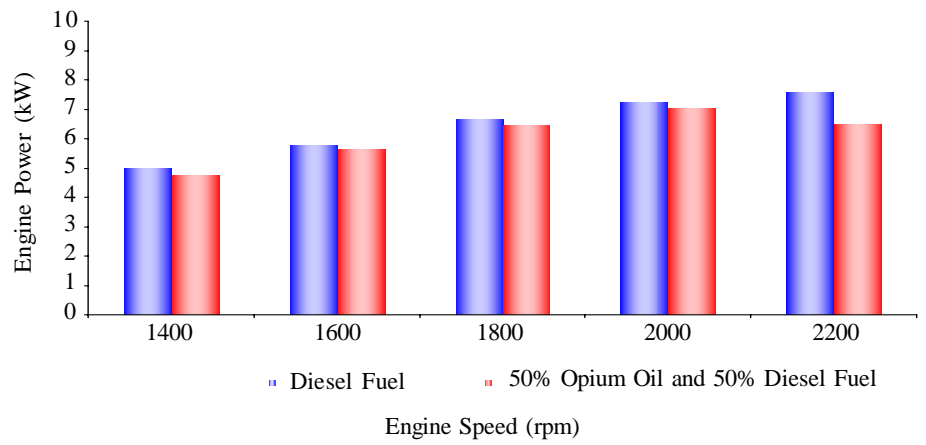

Fig. 3: The variation of engine power with engine speed

\section{Specific fuel consumption}

The variations of specific fuel consumptions of opium poppy oil-diesel fuel mixture and diesel fuel with engine speed are given in Fig. 4. While specific fuel consumptions are high at low engine speeds, they decrease with increasing engine speed up to $2000 \mathrm{rpm}$ and then they increase again beyond this speed. The specific fuel consumption of opium poppy oil-diesel fuel mixture is $17 \%$ higher than diesel fuel at $2000 \mathrm{rpm}$. In diesel engines, specific fuel consumption depends on fuel properties such as density, viscosity, and heating value (Usta et al., 2005). While viscosity and 
density of opium poppy oil-diesel fuel mixture are higher than of diesel fuel, heating value of it is lower. Higher density of opium poppy oil-diesel fuel mixture has led to pump more fuel for the same displacement of plunger in the fuel injection pump (Pramanik, 2003). High viscosity affects fuel vaporization, combustion, and atomization negatively (Kumar et al., 2003). These problems led to increases in specific fuel consumptions using of vegetable oils as alternative fuel.

\section{Exhaust emission}

The engine operating parameters such as air-fuel equivalence ratio, fuel type, combustion chamber design and atomization ratio affect with all emissions emitted by internal combustion engines. Especially, emissions of $\mathrm{CO}$ and unburned $\mathrm{HC}$ in the exhaust are very important since they represent the low chemical energy that cannot be totally used in the engine.
Emissions such as $\mathrm{CO}_{2}, \mathrm{NO}_{\mathrm{x}}$ and smoke emitted by especially diesel engines have important effects on ozone layer and human health (Ozsezen et al., 2009). $\mathrm{CO}$ emissions depending on many parameters such as air fuel ratio and engine temperature are very important for internal combustion engines. The variations of $\mathrm{CO}$ emissions with engine speed are given in Fig. 5 CO emissions for both fuel types increases up to $1800 \mathrm{rpm}$ engine speed and decrease beyond this speed. CO emissions of opium poppy oil-diesel fuel mixture compared with diesel fuel decreased by $15.5 \%$ as the average. Devan and Mahalakshmi (2009) reported that physical features of fuel such as viscosity and density affect engine performance and emissions negatively. Wang et al. (2006) observed that CO emissions of vegetable oils and vegetable oil-diesel fuel mixtures were lower than that of diesel fuel under full load conditions. The variation of $\mathrm{NO}_{\mathrm{x}}$ emissions with engine

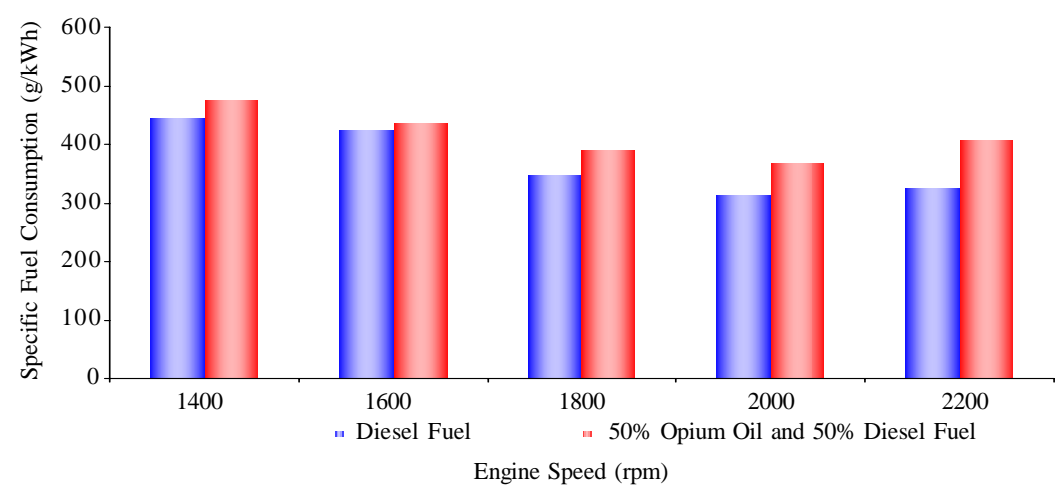

Fig. 4: The variations of specific fuel consumptions with engine speed

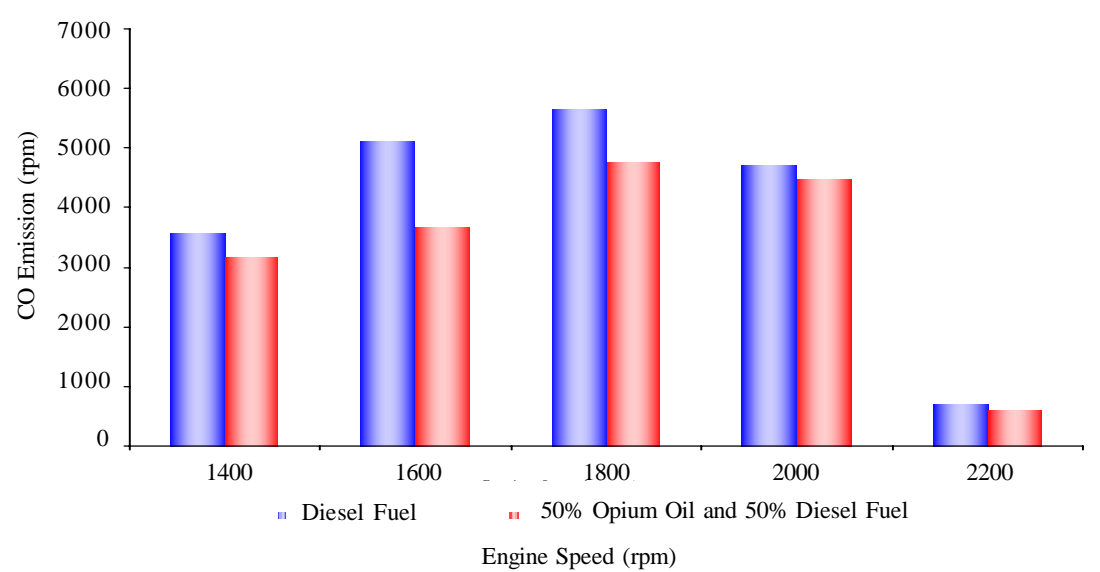

Fig 5: The variation of $\mathrm{CO}$ emission with engine speed 


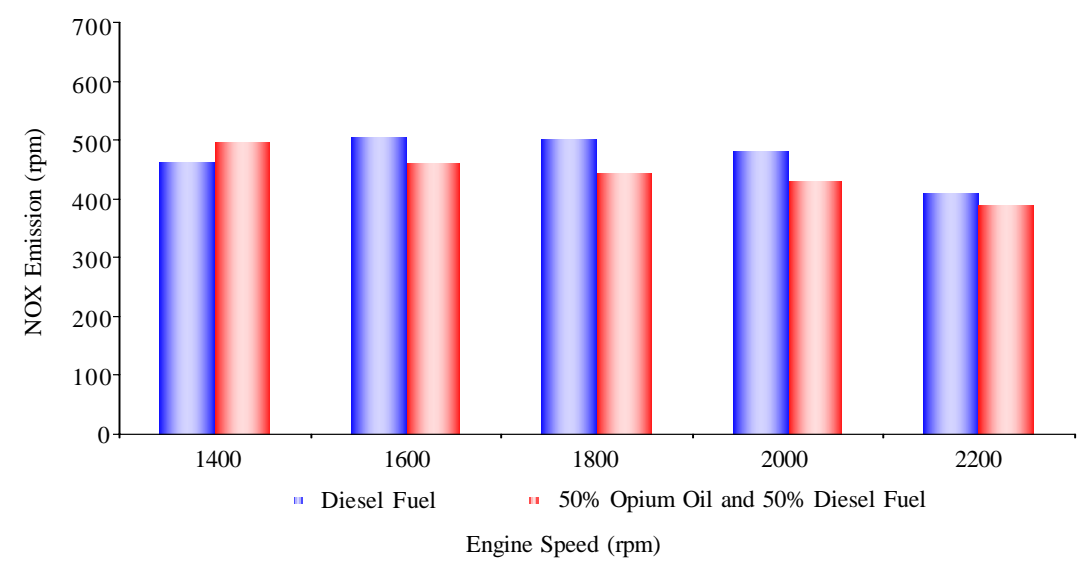

Fig. 6: The variations of $\mathrm{NO}_{\mathrm{x}}$ emission with engine speed

speed is given in Fig. 6. $\mathrm{NO}_{\mathrm{x}}$ emissions of diesel fuel increase up to $1600 \mathrm{rpm}$ engine speed and decrease beyond this speed. However, $\mathrm{NO}_{\mathrm{x}}$ emissions of opium poppy oil-diesel fuel mixture are highest level at 1400 rpm and decrease by increasing of engine speed. NOx emissions of mixture compared to diesel fuel decrease to $5.9 \%$ as average. Since the size of injected particles of vegetable oils is bigger than that of diesel fuel, combustion efficiency and maximum combustion temperatures with vegetable oils were lower. Therefore, $\mathrm{NO}_{\mathrm{x}}$ emissions were lower (Ramadhas et al., 2004).

\section{CONCLUSION}

Recently, the researches on alternative energy sources have increased due to fossil fuels depletion and environmental degradation. Alternative fuel, which can be used without modification since the invention of diesel engines, is vegetable oils. In this study, the effects of opium poppy oil-diesel fuel mixture on engine performance and emission are investigated and these results are obtained.

- While density and viscosity of opium poppy oildiesel fuel mixture is higher than that of diesel fuel, lower heating value of it is lower.

- By the usage of opium poppy oil-diesel fuel mixture, while an average decrease of $4 \%$ and $5.73 \%$ are observed in engine torque and power respectively, an average increase of $12 \%$ is observed in specific fuel consumption. This decrease in engine performance is caused by the low heating value.

- $\mathrm{CO}$ and $\mathrm{NO}_{\mathrm{x}}$ emissions of opium poppy oil-diesel fuel mixture compared with diesel fuel decreased by $15.5 \%$ and $5.9 \%$ as the average respectively.
- Opium poppy oil-diesel fuel mixture can be used as alternative fuel for vehicles with diesel engine.

\section{ACKNOWLEDGEMENTS}

The author wish to express his thank to Assoc. Prof. Dr. Hüseyin Bayrakçeken for his helpful comments and advice.

\section{REFERENCES}

Agarwal, A. K.; Rajamanoharan, K., (2009). Experimental investigations of performance and emissions of Karanja oil and its blends in a single cylinder agricultural diesel engine. Appl. Energ., 86 (1), 106-112 (7 pages).

Agarwal, D.; Kumar, L.; Kumar Agarwal, A., (2008). Performance evaluation of a vegetable oil fuelled compression ignition engine. Renew. Energ., 33 (6), 11471156 (11 pages).

Aksoy, F.; Baydýr, S.A; Bayrakçeken, H.; Yavuz, H., (2008). The effects of application of pre-heating process to biodiesel fuel on engine performance and emissions. 10. Int. Combust. Symp. Sakarya, Turkey 9-10 October.

Akta, A.; Sekmen, Y., (2008). The effects of advance fuel injection on engine performance and exhaust emissions of a diesel engine fuelled with biodiesel. J. Fac. Eng. Arch. Gazi Univ., 23 (1), 199-206 (8 pages).

Alptekin, E.; Çanakçý, M., (2009). Characterization of the key fuel properties of methyl ester-diesel fuel blends. Fuel, 88 (1), 75-80 (6 pages).

Altýn R.; Yücesu H.S.; Çetinkaya S., (2001). The potential of using vegetable oil fuels as fuel for diesel engines. Energ. Convers. Manage., 42 (5), 529-538 (10 pages).

Altun, A.; Bulut, H.; Öner, C., (2008). The comparison of engine performance and exhaust emission characteristics of sesame oil diesel fuel mixture with diesel fuel in a direct injection diesel engine. Renew. Energ., 33 (8), 1791-1795 (6 pages).

Babel, S.; Sae-Tang, J.; Pecharaply, A., (2009). Anaerobic co-digestion of sewage and brewery sludge for biogas production and land application. Int. J. Environ. Sci. Tech., 6 (1) 131-140 (10 pages) 
Baiju, B.; Naik, M. K.; Das, L. M., (2009). A comparative evaluation of compression ignition engine characteristics using methyl and ethyl esters of Karanja oil. Renew. Energ., 34 (6),1616-1621 (6 pages)

Çanakçý, M.; Van Gerpen, J., (1999). Biodiesel production via acid catalysis. Am. Soc. Agri. Eng., 42 (5),1203-1210 (8 pages).

Çanakçý, M.; Özsezen, A. N.; Türkcan, A., (2009). Combustion analysis of preheated crude sunflower oil in an IDI diesel engine. Biomass Bioenerg., 33 (5), 760-767 (8 pages).

Çaynak, S.; Gürü, M.; Biçer, A.; Keskin, A.; Ýçingür, Y., (2009). Biodiesel production from pomace oil and improvement of its properties with synthetic manganese additive. Fuel, 88 (3), 534-538 (5 pages)

Çevik, Ý.; Bulut, C.; Karabekta, M.; Ergen, G., (2008). The effects of supplementary air application on the performance of a diesel engine fuelled with biodiesel produced from waste vegetable oil. 10. Int. Combust Symp. Sakarya, Turkey 9-10 October.

De Oliveira Matias, J. C.; Devezas, T. C., (2007). Consumption dynamics of primary-energy sources: The century of alternative energies. Appl. Energ., 84 (7-8), 763-770 (8 pages).

Devan, P. K.; Mahalakshmi, N. V., (2009). Performance, emission and combustion characteristics of poon oil and its diesel blends in a DI diesel engine. Fuel, 88 (5), 861-867 (8 pages).

El Diwani, G.; El Rafie, S., (2008). Modification of thermal and oxidative properties of biodiesel produced from vegetable oils. Int. J. Environ. Sci. Tech., 5 (3), 391-400 (10 pages).

Haktanýrlar Ulutas, B., (2005). Determination of the appropriate energy policy for Turkey. Energy, 30 (7), 1146-1161 (16 pages)

Huzayyin, A. S.; Bawady, A. H.; Rady, M. A.; Dawood, A., (2004). Experimental evaluation of Diesel engine performance and emission using blends of jojoba oil and Diesel fuel. Energ. Convers. Manage., 45 (13-14), 20932112 (16 pages).

Kalam, M. A.; Husnawan, M.; Masjuki, H. H., (2003). Exhaust emission and combustion evaluation of coconut oil-powered indirect injection diesel engine. Renew. Energ., 28 (15), 2405-2415 (11 pages).

Kalam, M. A.; Masjuki, H. H., (2004). Emissions and deposit characteristics of a small diesel engine when operated on preheated crude palm oil. Biomass Bioenerg, 27 (3), 289297 (9 pages).

Kaygusuz, K.; Sarý, A., (2003). Renewable energy potential and utilization in Turkey. Energ. Convers. Manage., 44 (3), 459-478 (19 pages).
Keskin, A.; Gürü, M.; Altýparmak, D., (2007). Biodiesel production from tall oil with synthesized $\mathrm{Mn}$ and $\mathrm{Ni}$ based additives: Effects of the additives on fuel consumption and emissions. Fuel, 86 (7-8), 1139-1143 (5 pages).

Kumar, M. S.; Ramesh, A.; Nagalingam, B., (2003). An experimental comparison of methods to use methanol and Jatropha oil in a compression ignition engine.Biomass Bioenerg, 25 (3), 309-318 (10 pages).

Özsezen, A. N.; Çanakçý, M.; Türkcan, A.; Sayýn, C., (2009). Performance and combustion characteristics of a DI diesel engine fueled with waste palm oil and canola oil methyl esters. Fuel, 88 (4), 629-636 (7 pages).

Panjeshahi, M. H.; Ataei, A., (2008). Application of an environmentally optimum cooling water system design in water and energy conservation. Int. J. Environ. Sci. Tech., 5 (2) 251-262(12 pages).

Pramanik, K., (2003). Properties and use of jatropha curcas oil and diesel fuel blends in compression ignition engine. Renew. Energ., 28 (2), 239-248 (10 pages).

Ramadhas, A. S.; Muraleedharan, C.; Jayaraj, S., (2005). Performance and emission evaluation of a diesel engine fueled with methyl esters of rubber seed oil. Renew. Energ., 30 (12), 1789-1800 (12 pages).

Ramadhas, A. S.; Jayaraj, S.; Muraleedharan, C., (2004). Use of vegetable oils as I.C. engine fuels-A review. Renew. Energ., 29 (5), 727-742 (16 pages).

Refaat, A. A.; Attia, N. K.; Sibak, H. A.; El Sheltawy, S. T.; ElDiwani, G. I., (2008). Production optimization and quality assessment of biodiesel from waste vegetable oil. Int. J. Environ. Sci. Tech., 5 (1), 75-82 (8 pages).

Refaat, A. A., (2009). Correlation between the chemical structure of biodiesel and its physical properties. Int. J. Environ. Sci. Tech., 6 (4) 677-694 (18 pages).

Refaat, A. A., (2010). Different techniques for the production of biodiesel from waste vegetable oil. Int. J. Environ. Sci. Tech., 7 (1) 183-213(31 pages).

Usta, N.; Öztürk, E.; Can, Ö.; Conkur, E. S.; Nas, S.; Çon, A. H.; Can, A. Ç.; Topçu, M., (2005). Combustion of biodiesel fuel produced from hazelnut soapstock/waste sunflower oil mixture in a Diesel engine. Energ. Convers. Manage., 46 (5), 741-755 (15 pages)

Wang, Y. D.; Al-Shemmeri, T.; Eames, P.; McMullan J.; Hewitt, N.; Huang, Y.; Rezvani, S., (2006). An experimental investigation of the performance and gaseous exhaust emissions of a diesel engine using blends of a vegetable oil. Appl. Therm. Eng., 26 (14-15), 1684-1691 (8 pages).

Yavuz, H.; Aksoy, F.; Bayrakçeken, H.; Baydýr, S. A., (2008). The Production of Various Vegetable Oil Methyl Esters and Comparison of Their Physical and Chemical Properties. Electron. J. Mach. Tech., 5 (2), 23-30 (8 pages).

\section{AUTHOR (S) BIOSKETCHES}

Aksoy, F., Researh Assistant is the Department of Machine Education, Technical education Faculty, Afyon Kocatepe University, Afyonkarahisar and a PhD student in Machine Education Department at the Gazi University, Ankara, Turkey. Email: faksoys@gmail.com 